\title{
ANALYSIS OF THE KENDARI CITY GOVERNMENT STRATEGY IN MAINTAINING FOOD SECURITY DURING THE COVID-19 PANDEMIC
}

\author{
Yully Angryanthy Salam ${ }^{1 *}$, Haji Saediman ${ }^{1)}$, Muhammad Aswar Limi ${ }^{1)}$ \\ ${ }^{1}$ Department of Agribusiness, Faculty of Agriculture, University of Halu Oleo Kendari 93232 \\ ${ }^{*}$ Corresponding author: yullyangryanthy7@gmail.com
}

To cite this article:

Salam, Y., Saediman, H., \& Limi, M. (2021). Analysis of the Kendari City Government Strategy in Maintaining Food Security During the Covid-19 Pandemic. International Journal of Agricultural Social Economics and Rural Development (ljaserd), 1(2), 50 - 55. doi:http://dx.doi.org/10.37149/ijaserd.v1i2.19405

Received: July 06, 2020; Accepted: July 11, 2020; Published: July 12, 2020

\begin{abstract}
The Covid-19 pandemic that has taken place since December 2019 affects various aspects of socio-economic life, including in the fulfillment of food needs. The research aims to find out the strategic priorities of the Kendari City government in maintaining food security during the Covid-19 Pandemic. The informants were two persons from the offices of Food Security and Agriculture Services at Kendari City government. Data were analyzed using descriptive qualitative analysis. The results showed that the Kendari City government in maintaining food security during the Covid-19 Pandemic took five strategies, namely (i) providing social assistance to affected communities, (ii) guaranteeing food distribution, (iii) monitoring and maintaining inflation rates, (iv) increasing food production, and ( $\mathrm{v}$ ) diversification of food and commodities.
\end{abstract}

Keywords: Covid-19 Pandemic; food security; government strategy

\section{INTRODUCTION}

Food security, according to Law Number 18 of 2012 regarding Food, is the condition of fulfilling food for the state to individuals, which is reflected in the availability of sufficient food, both in quantity and quality, being safe, diverse, nutritious, evenly distributed and affordable and does not conflict with religion, belief, and community culture, to be able to live a healthy, active, and productive life in a sustainable manner. Maintaining food security is crucial for strengthening economic and political stability. Guaranteed food availability at affordable prices can be realized through increased production. Food security remains a fundamental problem in most countries due to, among others, increased population, increased purchasing power, and climate change. To support national food security, it is necessary to take measures at the household level, such as farming in the yard(Purwantini, 2016).

The World Health Organization (WHO) explains that Coronaviruses (Cov) infect the respiratory system. This viral infection is called COVID-19. The spread of the coronavirus is swift, even across countries(Hanoatubun, 2020).

Food security is one of the essential things during the Covid-19 Pandemic. It can cause various problems, including disruption of production, distribution, and consumption of basic needs due to large-scale social restrictions and travel bans for the community. This condition can trigger concerns if Indonesia experiences a food crisis. In Indonesia, the Covid-19 virus has a significant and massive impact because it affects the cessation of vital sectors, one of which is the food distribution sector (Surni et al., 2021).

Various parties worldwide have carried out all aspects of prevention and countermeasures against the pandemic from March 2020 until now. Efforts to address its effect have depended on the level of Covid-19 infections. While some countries implemented lockdown, the Indonesian government applied Large-Scale Social Restrictions(PSBB). The PSBB restricts people's movement and encourages them to do various activities at home, thus reducing physical contact. This virus disrupts many sectors that support community life, including the agricultural industry (Wulandari \& Anggrani, 2020).

Fiandana, (2015) conducted research entitled The strategy of The Local Government in Increasing the Local Food Security (The study was conducted in Malang). The development of food 
security is the responsibility of the government as well as the local community. The excellent collaboration between them will help develop high food security in providing food for the entire population, especially the food derived from the local production. In addition, the increased food security level is expected to provide food insufficient and affordable quantities and variations. To create these conditions, a strategy is needed to improve food security itself. Local Government of Malang and Badan Ketahanan Pangan Pelaksana dan Penyuluhan (BKP3) have sought to improve regional food security by developing the community rice barn, diversifying the variety of food and nutrient, forming Dewan Ketahanan Pangan (Food Security Board), and applying Program Desa Mandiri Pangan (Food Self-Sufficient Village). The result showed that the approach used by the local government of Malang in improving the food security had met the demand of the food security aspects.

Diwangkara, (2020) conducted research entitled Efforts to Defend Countries through Food Security in the Covid-19 Pandemic. The impact of the Covid-19 pandemic has been seen in various aspects of life, ranging from health, social, economic, and multiple others, in most parts of the world, including in Indonesia. Recently, food security has become a topic in public conversation due to Indonesia's increasingly widespread Covid-19 Pandemic. Food is a significant milestone for the needs of the people of Indonesia. Therefore, many parties need special attention in meeting the community's needs and improving food welfare during the Covid-19 Pandemic.

Kendari City is one of the areas in Southeast Sulawesi that has been affected by the coronavirus. The Kendari City Government is trying its best to deal with the Covid-19 Pandemic to reduce the number of new positive cases so that they can get out of the circle and shadow of the virus. The Kendari City Agriculture Office, Southeast Sulawesi, continues to encourage farmers in the region to remain productive to help improve the economy in the city, especially during the Covid-19 Pandemic.

In the strategy for agricultural development goals, several things to consider are as follows. (1) Strategy implementation, which is a policy in implementing strategy through a rigorous identification method and relates to the elements of environmental management both internally and externally, as well as efforts to align organizational goals, so that policies for that implementation can be expected to be even better because it is supported by collaboration and sustainable implementation efforts in each policy-focused. (2) Strategy evaluation is the final policy, where at this stage, the strategy that has been implemented need to be assessed whether it has been successful or not so that if there are some shortcomings in its implementation, it can be followed up at this stage; it is also hoped that there will be expectations of real organizational achievement. The success or failure in implementing development policies in the agricultural sector can be measured from the indicators of the strategy's success so that the implementation can be maximized. (Pratama, 2020). This study aimed to analyze the strategy of the Kendari City government in maintaining food security during the Covid-19 Pandemic.

\section{MATERIALS AND METHODS}

This research was conducted in June 2021 in Kendari City, Southeast Sulawesi Province. The research location was determined purposively considering that Kendari City has the highest number of cases exposed to Covid-19 in Southeast Sulawesi Province. Respondents in this study were selected purposively and accounted for three people. The respondents in this study consisted of the Head of the Food Crops Division of the Kendari City Agricultural Service, the Head of the Food Availability and Insecurity Division of the Kendari City Food Security Service, and the Lecturer of the Faculty of Agribusiness, Halu Oleo University. The data in this study consisted of primary data and secondary data. Preliminary data were obtained through in-depth interviews with predetermined informants. At the same time, the secondary data used in this study were obtained from Badan Ketahanan Pangan (BKP).

Researchers used several data collection techniques, namely desk study, interviews (interviews), and questionnaires. Variable research is derived from the study of literature and in-depth interviews with the respondents about the strategy of the Kendari city in maintaining the resilience of food in times of the Covid-19 pandemic. Variables are some criteria and alternative methods that will be determined based on interviews and literature study results. 


\section{RESULTS AND DISCUSSION}

\section{Overview of Respondents}

One respondent serves as the Head of division Food Crops Division at the Agriculture Service Agency of Kendari Municipality The resource person has an educational background in Agronomy. The respondent is responsible for leading, coordinating, and controlling food crop agriculture management, including facilities and infrastructure, product development, processing, and marketing of products.

Another respondent is the Head of Food Availability and Insecurity Division at Food Security Office of Kendari City., The resource person has an educational background in Food Technology. Respondent is responsible for preparing materials for the formulation and implementation of policies and evaluation and reporting in food security and food insecurity.

\section{The strategy of Kendari City Government in Maintaining Food Security during the Covid- 19 Pandemic}

\section{Increased Food Production}

The eating habits of a person or community in selecting what food is consumed in response to physiological, psychological, and socio-cultural influences or the impact of a state of emergency can be changed. At this time, the Covid-19 pandemic makes the community do many activities from home(Saragih \& Mulawarman, 2020).

It was revealed from the interviews that Urban farming is one of the strategies promoted by the Kendari City government during the pandemic. One of them is that the Covid-19 Pandemic has made the government issue a Work From Home (WFH) policy, making people stay at home more and look for new activities not to feel bored but remain productive. Urban farming is farming in urban areas by utilizing open fields that surround the community. The average land area used is 5-50 $\mathrm{m}^{2}$. Commonly cultivated commodities are short-lived plants such as various leaf and fruit vegetables, medicinal plants, and ornamental plants. The development of urban farming is a program specifically designed to increase agricultural productivity by utilizing yard land to meet daily food needs. It was understood from the interviews that the efforts to develop urban farming in Kendari were made through empowerment by forming a community gardening or Women Farmers Group (KWT). The development of Urban Farming is also a form of implementing Kendari City Government policies that aim to increase community empowerment.

One form of Urban Farming is the Sustainable Food House Area (KRPL) program. KRPL is a central government program implemented throughout Indonesia, including in Kendari City. KRPL is carried out every year in Kendari City by selecting several districts as pilot locations. KRPL aims to help improve household food security by increasing the quantity, quality, and diversity of food through yards. The research results by Saediman et al. (2021a) show that the KRPL program improves the food security of the program participants' households from food availability, access, and utilization. However, the challenge of this KRPL program is its sustainability, so the benefits of food security tend to decrease when the program ends (Saediman et al., 2021a).

(Amir \& Saidin) research shows that urban farming development efforts are carried out by empowering the community by forming gardening communities or women's farmer groups. Still, economically the outcome from this effort has not been felt by the community because this activity has not increased community self-help and self-financing. However, from the social side, this activity has built community relations with the formation of gardening communities or farmer groups, leading to better relationships between individuals through joint activities. Farmer groups still need assistance for the supply of seeds, fertilizers, skilled workers, and assistants.

\section{Providing Social Assistance to Affected Communities}

To overcome the impact of the Covid-19 pandemic on various socio-economic aspects, including food security, the government provides multiple social assistance packages or schemes to affected communities. The sources of the social service budget are APBN (central government budget), Provincial APBD, and Kendari City APBD. Examples of social assistance include the Family Hope Program (PKH), Non-Cash Food Assistance, Food Social Assistance, Cash Social Assistance, MSME Assistance, Pre-Employment Programs, Electricity Subsidies, and Bank Loan Relief.

The Ministry of Agriculture gave directions that the Covid-19 pandemic was momentum for reforming the food sector. Indonesia is required to meet all domestic food needs. So, the primary step taken by the government is to increase national production based on smallholder agriculture and take sides with small farmers. To make it happen, the government has reallocated a larger budget to be 
allocated in seed assistance. The budget reallocation is the government's capital to boost food production and improve farmers' welfare.

In Kendari City itself, through the Dinas Pertanian Kota Kendari, the local government continues to provide stimulants in the procurement of seeds, fertilizers, and pesticides to farmers scattered throughout the Kendari City are, pesticides for farmers affected by Covid-19. The funds used were also obtained from the Covid assistance fund issued by the Kendari City government to farmers affected by the Covid-19 pandemic to procure seeds, fertilizers, and pesticides. To maintain people's purchasing power during the Covid-19 pandemic, The government has also provided a fiscal stimulus of Rp405,1 trillion, of which Rp110 trillion will be allocated in the form of a social safety net, including additional beneficiaries Family Hope Program (PKH), basic food cards (Non-Cash Food Assistance (BPNT)), pre-paid cards work, discounted electricity rates (for 450 and 900VA customers), fulfillment of basic needs and market operations, and adjustment of education budgets. This can at least reduce the burden borne by the community, especially low-income people or people who are vulnerable to the impact of the social and economic spread of Covid-19 (Hirawan, 2020).

\section{Food and Commodities diversification}

Diversification of agricultural commodities is allocating agricultural resources to several other economically and environmentally beneficial activities. Commodity diversification can lead to planting various types of plants in one land, keeping different kinds of livestock in one cage, to using land for commercial purposes such as restaurants serving agricultural products (farm-to-table marketing method ). Agricultural diversification is believed to answer agricultural challenges during the Covid-19 Pandemic, which impacts purchasing power uncertainty so that production variations can save farmers' income. Respondents revealed that food diversification in Kendari City uses local food.

(Abidin \& Musadar, 2018) research results show that sago local food, which was initially a local food for Tolaki ethnic communities in Kendari City, has now developed and has become a potential food and beverage "favorite" food for Kendari City. Public perception of food Local sago is classified as a high category with an average score of 93,0. Ease in obtaining the type of local food is a perceptual parameter that occupies the highest category $(99,2)$, and the lowest in the perception parameter "Feeling bad" if in a week do not consume local food sago" with the level of perception classified as moderate $(64,8)$. In the future, local food perceptions still need to be implemented to support food diversification, which the government is currently promoting.

Food diversification policies are promoted primarily to reduce dependence on rice, which is currently the staple food of $97 \%$ of Indonesia's population (Saediman, Aisa, Zani, Limi, \& Yusria, 2019). The food diversification policy is suitable for promoting Southeast Sulawesi because of local staple foods such as corn, cassava, and sago (Saediman et al., 2021b).

Improved production and policies on local food are needed to support the emphasis on food diversification in the law regarding food. The development of food diversification needs to consider the following: (1) preparation of road map of production and special agro-industry for the development of local food to achieve diversification of production and diversification of food consumption; (2) policy diversification of food consumption accompanied/in line with production policy and processing industry; (3) strengthening implementation of food diversification policy to the regional level; (4) development and strengthening food production policies locally so that there are various types of local food available continuously and in accordance with needs by allocating proportional funding and make food production development by local government is also a mandatory business other than rice, corn, soybeans, and others (5) policy development and strengthening local food industry in each region to home industry, Small and Medium Enterprise and other types of other industries and (6) development of local food processing technology so that various local food products with affordable prices with good quality prime can be available. This local food product is also suitable for consumer preferences or becomes a driver to enjoy the product (Tyas, 2019).

\section{Food Distribution Guarantee}

Interviews revealed that during the Covid-19 pandemic, the uncertainty of market demand and the sluggishness of people's purchasing power made farmers hesitate to carry out production activities. Hence, the Kendari City government issued an Agricultural Product Protection strategy, namely providing guarantees for The distribution of agricultural products by absorbing the farmers' food products. To control inflation, various efforts have been made to reduce the consumer price index rate through the Mobile Farmers Market program. A routine activity carried out by the Agriculture Service to market farmers' agricultural products directly to consumers. This mobile market moves from one place to another and targets densely populated residential areas in the city. The implementation of the mobile farmer's market during the Covid-19 pandemic aims to improve the 
economy of local farmers by increasing the bargaining position of farmers as producers, namely by providing marketing facilities so that they can shorten the supply chain of vegetables to consumers so that consumers can get vegetables at more affordable prices.

\section{Monitoring and Maintaining the Inflation Rate}

The Kendari City government is trying to maintain prices for staple foods throughout the city. This effort is made so that amid the spread of the Coronavirus or Covid-19, all fees and costs for food needs are still affordable by the community to meet their basic food needs.

Price policy for rice, sugar, and soybean commodities in the first year of the Covid-19 pandemic has not shown partiality to farmers. The high price of rice at the retail level is not directly proportional to the increase in grain prices at the producer level. Sugar prices fluctuate because the sugar import period coincides with the sugar cane harvest period. The elimination of import tariffs to $0 \%$ allows domestic farmers to compete directly in the global market(Sari, 2021).

The Regional Food Security Task Force reported regularly to the Ministry of Home Affairs through a website-based application to maintain the stability of staple food prices and commodity supply. The data and information about strategic food stock and prices are obtained through monitoring carried out to market wholesalers. This activity is routinely carried out every Monday and Thursday by the Food Distribution Section, Food Availability and Insecurity Division, hoping that supply and price stability is controlled and the community needs in Kendari City can be met. As a result, there are no food shortages, especially during the Covid-19 pandemic. This routine monitoring covers 11 commodities, including rice, corn, garlic, shallots, red cayenne pepper, large chilies, chicken eggs, beef, meat, cooking oil, and sugar.

The Highest Retail Price (Harge Eceran Tertinggi or HET) is a government instrument as a price limit for market intervention in price stabilization. When food prices exceed a certain percentage of the HET, this signals the government to come to the market to intervene. One of the instruments is to conduct market operations to return to its normal position or below the HET. Thus, people's purchasing power is maintained, and inflation is controlled. However, HET does not stand alone in this case because it complements various other stabilization instruments such as food reserves, export and import regulations, and floor prices. The Highest Retail Price cannot be relied upon as an instrument of stabilization if no food reserve can be moved at any time to correct market failures. For food reserves to be safe, absorption from domestic production must be optimized. So, in this case, an introductory price instrument is needed, which in the terminology of Rice Instruction No. 5/2015 is called the Government Purchase Price (HPP). The Government Purchase Price (HPP) acts as a shield so that farmers do not lose money. When the price of grain/rice falls below the HPP, Bulog will buy the farmers' produce. When the reserves are not enough, they can be met from imported rice outside the harvest season. If the price of grain/rice at the farmer or mill level is below the HPP, then the State Logistics Agency (Bulog) must absorb it while still paying attention to the quality requirements and following the HPP provisions. Gustiawan's research (2020) states that the Covid-19 pandemic has affected the price fluctuations of food commodities. The price disparity between producers or farmers and the consumer community is vast. Implementing PSBB in several areas has implications for hampering distribution from the production to urban areas as consumption centers.

For this reason, the agricultural business sector needs to adapt to these changes. The efficiency of the marketing chain of agricultural products needs to be created while still taking sides with the farmers. The Ministry of Agriculture has made efforts to create efficiency in the marketing chain, including optimizing and expanding the Mitra Tani Market and Farmer Shops to cover 34 provinces. Mitra Tani Market has been a link for Gapoktan (Farmer Groups Union), who want to sell their products directly to consumers. In the digital era, producers are also helped by the presence of several online-based delivery services.

\section{CONCLUSIONS}

Based on the results of research and discussion regarding the strategy of Kendari city government in promoting food security in the time of the Covid-19 pandemic, it can be concluded that the city government implemented five strategies, namely (i) providing social assistance packages or schemes to the affected people, (ii) ensuring food distribution, (iii) monitoring and keeping the inflation rate (iv) increasing food production, and (v) diversifying staple food and commodities. 


\section{REFERENCES}

Abidin, Z., \& Musadar, M. (2018). Analisis Persepsi Masyarakat Terhadap Pangan Lokal Sagu di Kota Kendari Sulawesi Tenggara. Jurnal Berkala IImiah AGRIDEVINA, 7(1), 1-13.

Amir, M., \& Saidin, S. Pengembangan Urban Farming dalam Rangka Pemberdayaan Masyarakat di Kota Kendari. Jurnal Neo Societal, 5(3), 227-237.

Diwangkara, C. J. A. a. S. (2020). Upaya Bela Negara Melalui Ketahanan Pangan Dimasa Pandemi Covid-19 (Efforts to Defend Countries through Food Security in the Pandemic COVID-19).

Fiandana, Y. J. J. A. P. (2015). Strategi Pemerintah Daerah Dalam Meningkatkan Ketahanan Pangan Daerah (Studi Pada Kabupaten Malang). 3(10), 1792-1796.

Hanoatubun, S. (2020). Dampak Covid-19 terhadap Prekonomian Indonesia. Journal of Education, Psychology, Counseling, 2(1), 146-153.

Hirawan, F. B. (2020). Kebijakan Pangan di Masa Pandemi Covid-19

Pratama, R. D. (2020). Strategi Dinas Ketahanan Pangan Dalam Pemenuhan Pangan di Kota Samarinda.

Purwantini, T. B. (2016). Potensi dan prospek pemanfaatan lahan pekarangan untuk mendukung ketahanan pangan. Paper presented at the Forum Penelitian Agro Ekonomi.

Saediman, H., Aisa, S., Zani, M., Limi, M., \& Yusria, W. (2019). Food Security Status of Households in A Cassava Growing Village in Southeast Sulawesi, Indonesia. Journal of Agricultural Extension, 12(1), 199-209.

Saediman, H., Gafaruddin. A., Hidrawati, H., Salam, I., Ulimaz, A., Rianse, I.S., Sarinah, S., Taridala, S.A.A. (2021a). The Contribution of Home Food Gardening Program to Household Food Security in Indonesia: A Review. WSEAS Transactions on Environment and Development 17 (in press)

Saediman, H., Helviani, H., Refiana, S., Sarinah, S., Taridala, S., Alwi, L., \& Sarimustaqiyma, R. (2021b). Market Structure of Sago Starch in Southeast Sulawesi, Indonesia. Wseas Transactions on Business and Economics. 18, 628-635.

Saragih, B., \& Mulawarman, U. (2020). Gambaran Kebiasaan Makan Masyarakat Pada Masa Pandemi Covid-19. Journal Research Gate, 19, 1-12.

Sari, N. A. (2021). Potret Perbandingan Kebijakan Harga Pangan Dengan Realita Harga Beras, Gula dan Kedelai di Tahun Pertama Pandemi Covid-19, Indonesia: The Portrait Comparison of Food Price Policies with Reality of Rice, Sugar and Soybean Prices in the First Year of Covid19 Pandemic, Indonesia. Journal Open Science Technology, 1(1), 82-104.

Surni, Nendissa, D. R., Wahib, M. A., Astuti, M. H., Arimbawa, P., Kapa, M. M., . . Food. (2021). Socio-economic impact of the Covid-19 pandemic: Empirical study on the supply of chicken meat in Indonesia. Journal AIMS Agriculture \& Food, 6(1), 65-81.

Tyas, D. N. A. (2019). Implementasi Kebijakan Program Kawasan Rumah Pangan Lestari (KRPL) Dalam Meningkatkan Kesejahteraan Masyarakat. 1(1), 71-87.

Wulandari, B. R. D., \& Anggraini, W. 2020. Food Estate Sebagai Ketahanan Pangan di Tengah Pandemi Covid-19 di Desa Wanasaba. Jurnal Pengabdian Masyarakat Berkemajuan. 4(1). 